\title{
The New Combined Soy Beverage for Elderly People: the Technology Process and the Use
}

\section{Marina V. Palagina ${ }^{1 *}$, Natalia G. Plekhova², Evgeniya S. Fishchenko ${ }^{1}$, Elena I. Cherevach ${ }^{1}$ and Larisa A. Tekutyeva1}

${ }^{1}$ Laboratory of Fundamental and Applied Problems of Commodity, Far Eastern Federal University, Vladivostok, Russia

${ }^{2}$ Lab. pathomorphology and electron microscopy, Research Institute of Epidemiology and Microbiology, Siberian Branch of the Russian Academy of Medical Sciences,

Vladivostok, Russia

\begin{abstract}
This study was conducted to develop of functional beverages on the basis of cultured aqueous extraction of soya grains with added extracts from Schisandra chinensis. Formulas and technology for production of functional beverages on the basis of aqueous soya extract, extract of Schisandra chinensis berries and probiotic starters (Lactobacillus bulgaricus и Streptococcus thermophilus) have been developed. Shelf life of beverages has been determined. Quality and safety of developed products have been studied. Characterizing the chemical composition and nutritional value of combined soy beverage, we can conclude that they differ balanced protein composition, adjusted for fatty acid composition, have a low calorie, which is very important for the elderly and balanced mineral macronutrients. Soy fermented beverages "Taste of Health" has a high number of viable cells, the optimal pH, allowing lactic acid bacteria remain in the active state during storage. All this makes it possible to call the resulting drink probiotic drinks functionality.
\end{abstract}

Keywords: Soy beverages; Berries; Schisandra chinensis; Polyphenols; Probiotics; Lactic acid bacteria

\section{Introduction}

It has been established that the basis for maintenance of well-being and active and long life is wholesome food. Diet and nutrition are key factors that impact on the health of elderly people and a healthy diet and lifestyle can help prevent disease, particularly chronic disease. The physiological changes associated with ageing result in older people having some specific nutritional needs that differ from the rest of the population. It is the food what is related with so-called "diseases of civilization" typical for elderly people, such as immunodeficiency, hypertension, chronic heart disease, osteoporosis, obesity, cancer, allergy, diabetes mellitus, dysbacteriosis and many others [1]. Market research of functional foods for the elderly people brings us to the conclusion that the line of geriatric dietary products is quite limited. So far, this segment is mainly represented with fermented milk products and canned meat and cereal foods [2,3]. Probiotic yoghurts and drinks are marketed as a health promoting alternatives to nonprobiotic yoghurts or drinks. In particular they are marketed as improving gut health and general immunity [4].

Soy products offer a considerable appeal for a growing segment of consumers with certain dietary and health concerns. It is quite evident that soy products do reduce the risks of developing various age-related chronic diseases and epidemiologic data strongly suggest that populations that regularly consume soy products have reduced incidence and prevalence of the aforementioned age-related conditions and diseases than populations that eat very little soy [5]. The dry soybean contains roughly $40 \%$ protein, $20 \%$ oil, $35 \%$ soluble (sucrose, raffinose, stachyose, etc.) and insoluble (dietary fiber) carbohydrate. Fresh soybean has approximately $14 \%$ moisture. Aqueous extract of soya is an ideal substitute of animal milk for people suffering from allergic, gastrointestinal and other diseases peculiar to elderly people $[6,7]$. Soymilk is used in various products like paneer, yogurt, cheese, tea and coffee whiteners, shrikhand, rasogolla and various indigenous milk sweets, confectionary, etc. [8,9]. During the last years, soy beverages consumption has gradually increased due to their significant concentration of health-promoting compounds, such as isoflavones.
The average daily soybean intake is $17-36 \mathrm{~g}$ in Japan, Korea, Taiwan, and Indonesia compared with $4 \mathrm{~g}$ in the United States [10].

Rich mineral composition of soya extract, particularly calcium and iron salts, makes it a healthy product for the people suffering from cardiovascular diseases, osteoporosis, nervous system disorder, anemia. Epidemiological data have indicated that Asian populations consuming soy as a dietary staple have a lower risk for cardiovascular diseases than those consuming a Western diet $[11,12,13]$. Cultured soya beverages fermented by lactic-acid bacteria beneficial to human health are high-technology products which can be easily used for the development of new types of products [14].

The effect of functional soya products in the management of the elderly people's health can be enhanced by introduction of biologically active components produced from the relevant raw materials. Some of such raw materials which are of special interest are berries vines of the Far Eastern region, among which a specific place is held by Schisandra chinensis (Chinese magnolia vine). Schisandra chinensis is a well-known Traditional Chinese Medicine. It has been used as an anti-tussive, a tonic, a sedative agent and, in traditional medicine, to improve the liver function of patients with viral hepatitis [15]. The dried berries of $S$. chinensis have been used for several thousand years in China. In Japan, Schisandra berries is a widely used component of Kampo medicines and, in the United States, it is a dietary supplement [16]. The main constituents of $\mathrm{S}$. chinensis are schizandrin derivatives, and the active principles are lignans with a dibenzocyclooctadiene skeleton [17].

*Corresponding author: Marina V. Palagina - B.D., Professor of cathedra Chemistry and Technology of living systems Far Eastern Federal University, 8 Sukhanova, Vladivostok, Russia, Tel: +74232 406569; E-mail: marina-palagina@yandex.ru

Received April 26, 2013; Accepted May 22, 2013; Published May 30, 2013

Citation: Palagina MV, Plekhova NG, Fishchenko ES, Cherevach EI, Tekutyeva LA (2013) The New Combined Soy Beverage for Elderly People: the Technology Process and the Use. J Food Process Technol 4: 240. doi:10.4172/21577110.1000240

Copyright: (c) 2013 Palagina MV, et al. This is an open-access article distributed under the terms of the Creative Commons Attribution License, which permits unrestricted use, distribution, and reproduction in any medium, provided the original author and source are credited. 
Schisandrin B, anactive ingredient isolated from Fructus Schisandrae, has been shown to afford generalized tissue protection against oxidative damage in various organs, including the brain of experimental animals. Recent experimental findings have further demonstrated that Sch $B$ can protect neuronal cells against oxidative challenge [18]. The combined actions of Sch B offer a promising prospect for preventing or possibly delaying the onset of neurodegenerative diseases, as well as enhancing brain health [19]. In addition, Schisandra chinensis has been used traditionally to treat general fatigue, neurasthenia and are therapeutically beneficial by promoting humoral and cell-mediated immune responses $[20,21]$.

This study was conducted to develop of functional beverages for elderly people on the basis of cultured aqueous extraction of soya grains with added extracts from the berries of Schisandra chinensis.

\section{Materials and Methods}

\section{Materials}

Bacterial strains: In selection of bacterial strains (Streptococcus thermophiles, Lactobacillus bulgaricus or Bifidobacterium) used in the technology of probiotic beverages we took into consideration the physiological compatibility of various strains, their best ratio, resistance to the substrate containing organic raw materials, and total quantity of starter. In selection of starter population we also made provision for its production and price indicators and ultimate effect on the human organism. For preparation of combined drinks were chosen two types of standard dried cultures of Lactobacillus bulgaricus complying with requirements of Standard Specifications 1002-02-78965 and Streptococcus thermophilus complying with requirements of Standard Specifications 9229-030-01610209-95.

Characteristic of soya product: For creation of the beverages we used soya grains of «Primorskaya-13», «Venus», «Primorskaya-13» and «October 70» (GOST 17109 - 88 «Soya beans. Requirements for state purchases and deliveries») soya flour (GOST 3898), drinking water (Sanitary-epidemiological requirements 2.1.4.1074). Soy protein product, which is then called soy "milk", was prepared according to the technology of the company RASCO (Belgium). The soya beans were sorted, cleaned from dirt, washed and poured over with water, which was regularly discharged and replaced with new portions in order to prevent fermentation process. In 12-14 hours the swollen soya beans were washed with running water to remove the soya beans husk and comminuted in homogenizer; the resulting mass with thickness similar to the one of dough was mixed with water having $\mathrm{t}=90^{\circ} \mathrm{C}(300 \mathrm{~L}$ per 60 $\mathrm{kg}$ of dry beans). After soaking for $10-15 \mathrm{~min}$ at $90^{\circ} \mathrm{C}$, the mixture was then divided into aqueous extract and pulp. After that the aqueous soya extract was autoclaved at $\mathrm{t}=110^{\circ} \mathrm{C}$ for 20 minutes.

Principal technological parameters and content of macronutrients were determined both in the original soya grains and finished soya extract. The results compared with the same parameters of the cow milk are shown in table 1.

\section{Methods}

Extraction of berries: The berries of Schisandra chinensis (Schizandra chinensis Bail) were collected in autumn (September and October) 2009-2011 in the state of technical maturity in clean forest regions of Primorye (Russia). The characterization of raw materials was the following: vine berriess-berries were red, had a rounded shape, often deformed, a diameter of 5-9 $\mathrm{mm}$, in the flesh was one (two) bright yellowish-brown or light brown, round-kidney-shaped

\begin{tabular}{|l|l|l|l|}
\hline Parameters & $\begin{array}{l}\text { Soya Grains of } \\
\text { “Primorskaya-13” Variety }\end{array}$ & $\begin{array}{l}\text { Aqueous } \\
\text { Soya Extract }\end{array}$ & $\begin{array}{l}\text { Cow Milk (Gost } \\
\text { R 52090-03) }\end{array}$ \\
\hline Proteins, g & 39.6 & 3.6 & 3.2 \\
\hline Fats, g & 12.9 & 1.3 & 3.6 \\
\hline Carbohydrates, g & 25.3 & 1.6 & 4.8 \\
\hline Calcium, mg & 330 & 30 & 120 \\
\hline Phosphorus, mg & 580 & 46 & 110 \\
\hline Magnesium, mg & 250 & 16 & 14 \\
\hline
\end{tabular}

Table 1: Principal technological parameters and content of macronutrients in soya soya milk and cow milk, (per $100 \mathrm{~g}$ of product).

seed. Berries had weak spicy, bitter and sour odor, pungent flavor and characteristic burning sensation in the mouth. In the berries of Schisandra chinensis was determined: moisture content (gravimetric method), tannin content, extractives (refractometric method, GOST 28562), total acidity, sugar [22]. Amino nitrogen was determined by ninhydrin method [23].

The extracts from the berries of Schisandra chinensis were prepared in accordance with requirements of The USSR State Pharmacopoeia, 1968. After removal of the juice from the berries they were left in water for 4-5 days for fermentation. Fermented berries were washed under running water, was triturated through a sieve and the seeds were dried. The seeds were grinded, filled with a solution of ethyl alcohol $(95 \%)$ in the ratio of 1:3, left at room temperature for 7 days, shaking occasionally. Then this mixture was kept at $4^{\circ} \mathrm{C}$ for 2 days and was filtered.

Spectrophotometric measurements: Total phenolics (FolinCiocalteau Index) and Absorbances (Abs) were measured according to European Official Methods (1990). Tannins were determined according by method of permanganate titration of aqueous extract plant material [24]

High-performance liquid chromatography analysis of content berries Schisandra chinensis. The samples for chromatography were prepared this method: $200 \mathrm{~cm}^{3}$ of the mixture seeds in solution of ethyl alcohol were extracted three times in portions of chloroform $\left(150 \mathrm{~cm}^{3}\right)$, combined chloroform portion was washed with $100 \mathrm{~cm}^{3}$ of water and was dried in the presence of anhydrous sodium sulfate. The chloroform extract was evaporated on a rotary evaporator under reduced pressure. The oily residue $\left(156 \mathrm{mg}\right.$ ) of reddish color was dissolved in $3 \mathrm{~cm}^{3}$ of methanol was passed through the cartridge stacking "Diapak C16" washed cartridge $3 \mathrm{~cm}^{3}$ of methanol.

Content schisandrine and gomizina $\mathrm{A}$ of extracts berries was determined by HPLC [25]. The samples were filtered through Supelco Filter $(0.5 \mu \mathrm{m}$ pores $)$ and was analysis on the chromatograph «LaChrom», consisting of a SCL-10AVP system controller, two LC10ADVP pumps, a SPD-M 10 AVP detector, and an injection system full Rheodyne model 7725 (Rheodyne, Cotati, CA) equipped with a 50 $\mu l$ loop. The column used for this separation was «Agilent $\mathrm{C} 18$ » column ( $4 \mathrm{~mm} \times 250 \mathrm{~mm}, 150 \mathrm{~mm}, 4 \mu \mathrm{m}$ particles diameter) equipped with the column with a mobile phase of acetonitrile-water (45: 55, v/v). Samples of $50 \mu \mathrm{m}$ of extracts or calibration standards (ready reference samples and lignans) were directly injected onto the column. Detection was performed by monitoring the absorbance signals at $250 \mathrm{~nm}$ (lignans compounds) [26].

For determination of phenolic compounds by method of HPLC was used the chromatograph SPD - 10AVP the detector UV and visible regions of the spectrum of the company «SHIMADZU LC -10 ADVP» (Japan) with the column «Shim-pack CLC-ODS» $(6,0 \times 150 \mathrm{~mm})$. 
Detection was performed by monitoring the absorbance signals at 275 $\mathrm{nm}$ [27]. The retention times (RT) of the phenolic acid compounds, identified by comparison with the UV-Visible spectra of pure reference standards and by the injection of co-eluted samples (sample + standard), were as follows RT=4.281 min (Figure 1). The model solution samples were injected directly into the chromatographic system after filtration through $0.45 \mu \mathrm{m}$ (Teknokroma PTFE) and $0.2 \mu \mathrm{m}$ (Advantec MFS PTFE) membrane-filtered [28]. Analyses were carried out in duplicate.

Microbiological analyses: Beverage samples were analyzed to evaluate the presence of food pathogens like S. aureus coagulasepositive and Salmonella. Bacteria belonging to the indicator families Staphylococcaceae and Enterobacteriaceae, including E. coli glucuronidase-positive, were also sought and numbered. For each of the samples, $10 \mathrm{ml}$ of beverage were added to $90 \mathrm{ml}$ of peptone water (Oxoid, Basingstoke, UK) and homogenized for one minute in a Stomacher mixer (Seward, Thetford, Norfolk, UK). The homogenate was subjected to decimal serial dilutions in peptone water and $0.5 \mathrm{ml}$ of each dilution were plated in duplicate on MacConkey agar medium (Oxoid), MacConkey MUG (4-methyl- $\beta$-umbelliferil-dglucuronide) (Oxoid) and Mannitol Agar Salt medium (Chapman medium, Oxoid), to search, respectively, for Enterobacteriaceae, E. coli, and Staphylococcaceae, including S. aureus. After incubation for 2448 hours at $37^{\circ} \mathrm{C}$, typical colonies were counted. Colonies grown on Chapman medium and showing yellow halo of lecitinase precipitation, typical of S. aureus, were tested for coagulase enzyme.

Determinate of quality parameters of soya beverage: The measurement of $\mathrm{Zn}, \mathrm{Cd}, \mathrm{Cu}$ and $\mathrm{Pb}$ in samples was accomplished through multiple standard additions of $100 \mu \mathrm{L}$ of $1.00 \times 10^{-4} \mathrm{~mol} \mathrm{~L}^{-1}$ $\mathrm{Zn}^{2+}, 300 \mu \mathrm{L}$ of $1.00 \times 10^{-5} \mathrm{~mol} \mathrm{~L}^{-1} \mathrm{Cd}^{2+}$ and $300 \mu \mathrm{L}$ of $1.00 \times 10^{-5} \mathrm{~mol}$ $\mathrm{L}^{-1} \mathrm{~Pb}^{2+}$ to the electrochemical cell containing $20 \mathrm{~mL}$ of $0.2 \mathrm{~mol} \mathrm{~L}^{-1}$ sodium acetate and $1.0 \mathrm{~mL}$ of sample [29]. To avoid measurement interference due to metal adsorption on the working surfaces of the electrode system, electrodes were submitted to periodic cleaning with $20 \% \mathrm{HNO}_{3}$ (by volume) followed by a generous wash with ultrapure water. Experiments were performed in three replicates at $23^{\circ} \mathrm{C}$ and $\mathrm{pH}$ 4.0 , and preceded by a gentle $\mathrm{N}_{2}$ bubbling to prevent oxygen diffusion into the electrochemical cell ( 10 min for the supporting electrolyte and $1 \mathrm{~min}$ after metal addition).

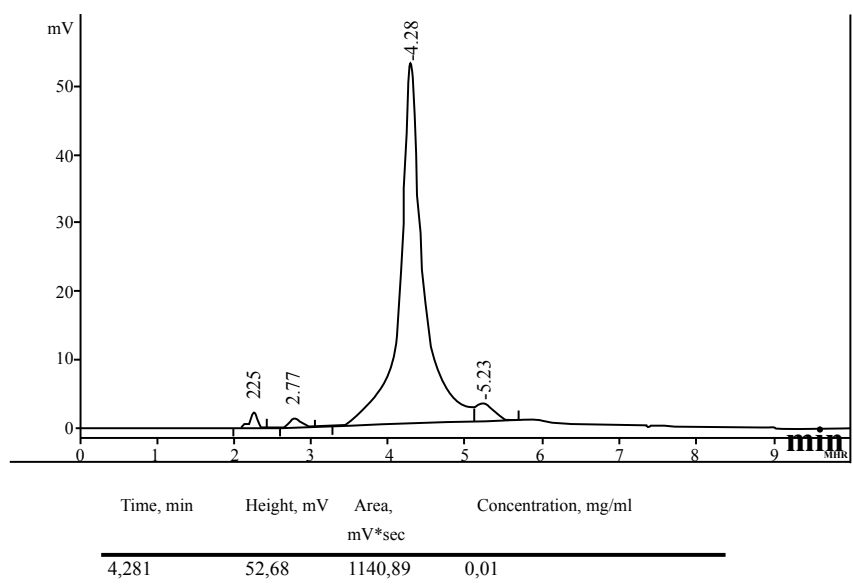

Figure 1: Chromatogram and identification of a standard solution of phenolic acid compounds, obtained in HPLC SPD - 10AVP (Detector UV and visible region of the spectrum) from SHIMADZU LC -10 ADVP with column «Shimpack CLC-ODS» $(6,0 \times 150 \mathrm{~mm})$ at $275 \mathrm{~nm}$
The reference material used for afloxin M1 and pesticide residues were procured from M/s Supelco Sigma, USA. Afloxin M1 was analyzed by using the Elisa Test Kit method of r-Biopharma: Ridascreen [30]. The residues of organochlorine (OCs), DDT and its metabolites, and $\alpha$-hexachlorocyclohexane, $\beta$-hexachlorocyclohexane and $\gamma$-hexachlorocyclohexane were analyzed using GC-MS following the MPRA S-9 method [31]. The determination of radionuclides in beverage carried out according to the method G.K. Murthy [32].

Sensory testing: The sensory testing was carried out following the Weibull Hazard method, where the initial number of panelists was $n_{0}=3$ and the constant with which the number of panelists was increased for each subsequent test was $n_{c}=1$. The interval between sensory testing was predetermined for each of the five different storage conditions. Because the spoilage of beverages at $14^{\circ} \mathrm{C}$ occurred at an accelerated rate, sensory samples were held overnight so that the sensory test could be carried out at a convenient time for the panelists. The panelists were prescreened and were required to meet the criterion that they consume at least one glass of beverages a day. A pool of 30 panelists who met this requirement, 12 male and 18 female, ranging in age from 35 to 65 were available for sensory testing. The panelists were financially compensated according to the number of samples that they tested.

For each sensory test a sample of beverage was taken from the beverage cartons, poured into a glass flask and the flask was immediately placed into an ice bath to slow down any microbial growth that might have caused any further deterioration of the sensory quality of the beverage. Approximately $10 \mathrm{ml}$ of beverage was poured into cups that were labeled with random three digit numbers for identification purposes. A tray of beverage samples for each of the panelists was prepared approximately half an hour to an hour before sensory testing took place. To ensure that the samples were all the same temperature when the panelists received their trays the trays were stored in conventional home refrigerators held at $4^{\circ} \mathrm{C}$. The trays, consisted of samples of beverages from the different storage temperatures.

Organoleptic assessment: Beverage samples of each variety were subjected to organoleptic assessment by a 10 -member panel. Clean cups were provided for each sample; each panelist was requested to taste the samples one after the other and to indicate their degree of likeness or preference for each on the questionnaire provided. The samples were evaluated for taste, sweetness, texture and odor. They were required to score each parameter on the scale of 1-4, depending on their degrees of acceptability; with 1 indicating strong acceptance and 5 indicating least acceptance.

\section{Results}

The pluripotent positive effect of Schisandra chinensis on the human organism can be attributable to its unique chemical composition. Other groups of active substances of the berries were demonstrated to belong to organic acids (citric, malic, tartaric and fumaric acids), sugars, phytosterols (e.g. stigmasterol), tannins, volatile oil compounds (monoterpenes, sesquiterpenes), vitamins (e.g. $\mathrm{C}$ and $\mathrm{E}$ ), and elements $\mathrm{Cu}, \mathrm{Mg}, \mathrm{Ni}$ and $\mathrm{Zn}[33,34,35]$. Chemical and technological characteristics of berries Schisandra chinensis that used for the preparation of the beverages are shown in table 2. Ethanol content of the solution and time of contact influence the extraction of components from both skins and seeds. To achieve complete extraction of these substances, it was necessary to select the optimal composition of the solvent - aqueous ethanol. On the basis of obtained preliminary results (Figure 2), in further work we used ethanol of $95 \%$ concentration. Composition and quantity of biologically active lignan compounds in 
the resulting extract were determined. Using high-performance liquid chromatography (HPLC), we determined the content of schizandrine and homizine $A$ in the extract equal to $3.2 \pm 0.2 \mathrm{mg} / \mathrm{L}$ and $3.4 \pm 0.2$ $\mathrm{mg} / \mathrm{L}$, respectively (Figure 3 ).

One of the most common phenolic compounds of berries and berries is phenolics compounds [35]. Because its water-and alcoholsoluble substance, he can go in extracts [27]. In the analysis of chromatograms seeds materials (water-alcohol extracts) showed that all the investigated berries contain phenolic acid compounds (Figure 3 ). Its retention time peaks were slightly shifted, so the routine was determined by method of "additives" [36].

Starter cultures of traditional yoghurts (Lactobacillus bulgaricus and Streptococcus thermophilus) are known to considerably promote the growth of their own flora present in the intestinal tract after getting into the human intestines. Their morphological and technological characteristics are shown in table 3. Using the selected culture for preparation of fermented beverages, we have provided the probiotic effect of finished products, which are known to be caused mainly antibiotic activity of lactic acid bacteria in relation to pathogenic and conditionally pathogenic microorganisms. Following the analysis of literature and a number of our own experiments we selected for preparation of the dietary beverages two species of microorganisms Lactobacillus bulgaricus и Streptococcus thermophilus. Their best ratio was 1:1, and the total quantity of the starter in accordance with formula was equal to $4 \%$ (Table 4$)$.

The technology of preparation of cultured beverages of "yoghurt" type (GOST R 51331-99) was taken as a basis for preparation of beverages on the basis of aqueous soya extract. The line with the general name: cultured soya beverages "Taste of health" (Technical Conditions 9184163-02067936-2007, Operational Procedure 163-2007) was developed. Cultured beverages "Taste of Health" were prepared in accordance with the procedure shown in figure 4 . Technology of the developed

\begin{tabular}{|c|c|}
\hline Indicators & Content (\%) \\
\hline Moisture content & $79.33 \pm 0.39$ \\
\hline Sugar & $2.76 \pm 0.01$ \\
\hline Total acidity & $5.52 \pm 0.07$ \\
\hline Extractives (dry basis) & $27.03 \pm 0.13$ \\
\hline Tannin (dry basis) & $4.47 \pm 0.04$ \\
\hline
\end{tabular}

Table 2: Chemical and technological characteristics of berries Schisandra chinensis.

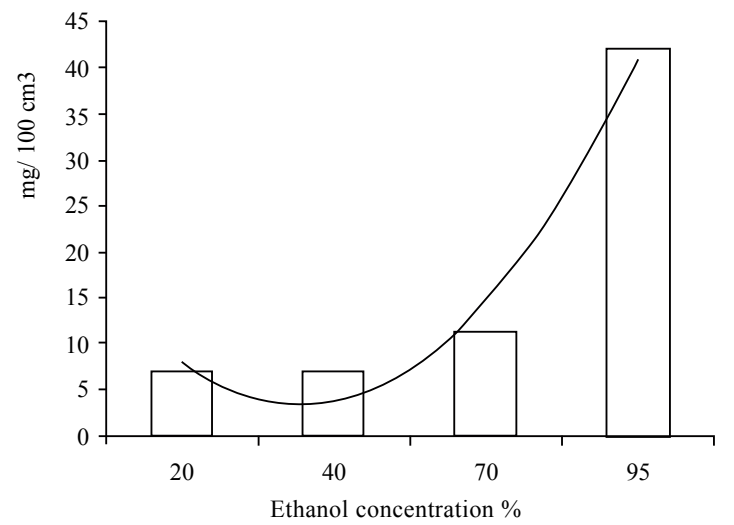

Figure 2: Content of extractive substances in extracts of Chinese magnolia vine seeds $\left(\mathrm{mg} / 100 \mathrm{~cm}^{3}\right)$.

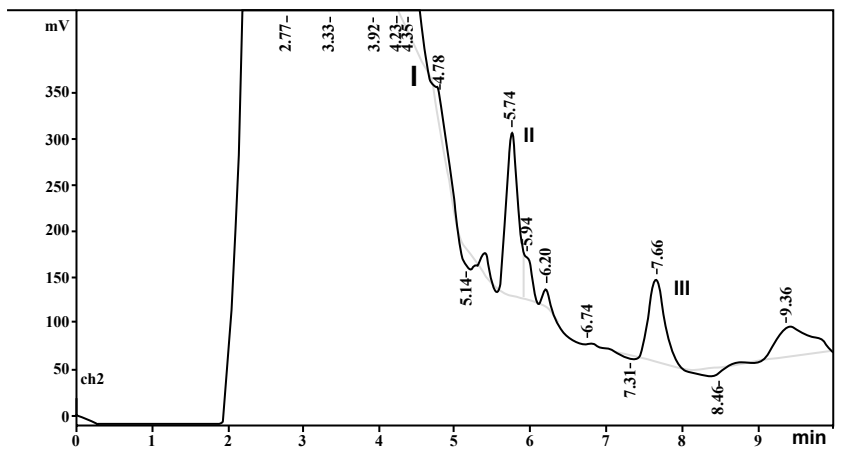

Figure 3: Chromatogram of extract of Chinese magnolia vine seeds (column "Shim-pack CLC-Pheny 1 », mobile phase - gradient of aqueous methanol): I - phenolic acid, II - schizandrine, II - homizine A.

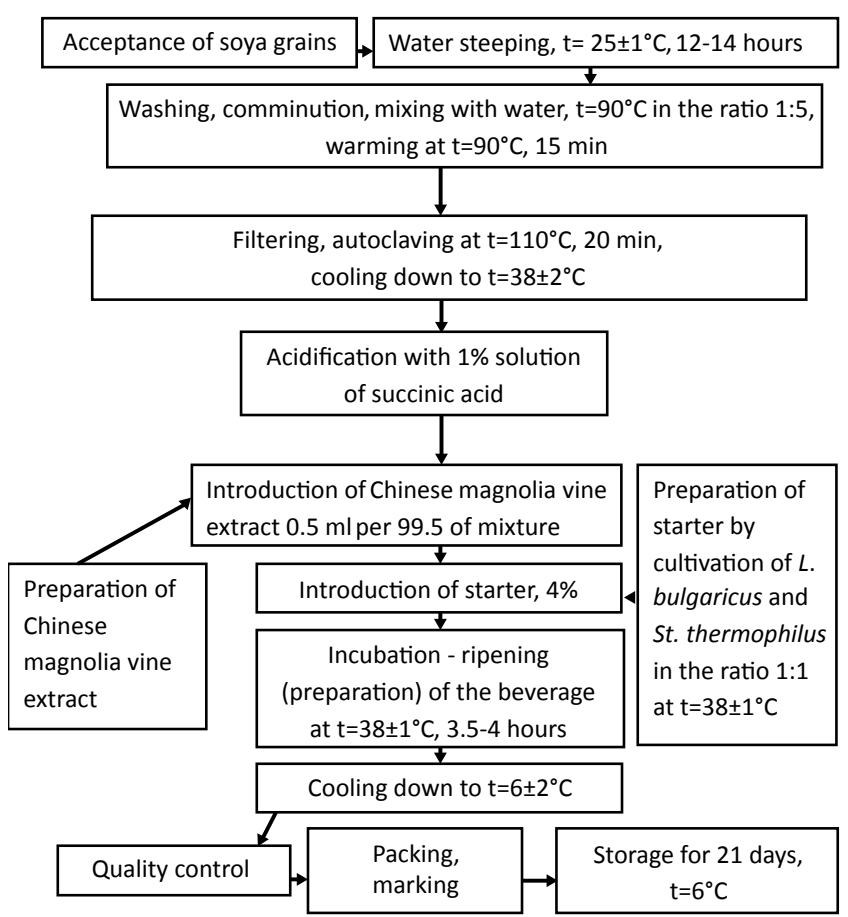

Figure 4: The scheme technology of preparation beverages "Taste of Health".

beverages included the following stages: preparation of soya extract, addition of succinic acid, addition of extract from Schisandra chinensis berries, introduction of starter, incubation - ripening (preparation) of the beverage at $\mathrm{t}=38 \pm 1^{\circ} \mathrm{C}$ for $4-6$ hours until the formation of a dense curd, cooling down to $\mathrm{t}=8 \pm 2^{\circ} \mathrm{C}$, quality inspection, packing, marking, storage.

For improvement of organoleptic indicators and nutritional and biological value some additional components, such as: succinic acid, berry syrups (GOST 28499-90); fruit juices (GOST R 52184-03); fruit nectars (GOST R 52187-03); concentrated fruit juices (GOST R 5218503); fresh berries and quick-frozen fruit and berries (GOST 29187-91); fruit and berry extracts (GOST R 52467-05); were introduced into the formula of cultured beverages enriched with extract of Schisandra 
chinensis seeds. The fillers were introduced either immediately before bottling (fruit and berry fillers) or in the course of preparation at an appropriate stage (succinic acid). Extracts from the fruit of Schisandra chinensis were prepared in accordance with requirements of The USSR State Pharmacopoeia (1968).

During study of quality of the developed beverages it was shown that their essential standard indicators comply with requirements of Sanitary Regulations and Standards 2.3.2.1078 (Table 5). The finished beverages "Taste of Health" are notable for their high nutritional value and large number of viable cells: content of lactic-acid bacteria in the beverages amounts to $1^{\star} 108(\mathrm{CFU} / \mathrm{cm} 3)$, and therefore they can be given the name of probiotic beverages. In studying of the chemical composition of the beverages it was shown that they feature wellbalanced protein composition (contain digestible proteins and all essential amino acids) and high content of essential fats (unsaturated fatty acids and phospholipids).

The results of organoleptic tests held in the course of development of cultured soya beverages were correlated with relevant properties of the traditional products - soya beverages of "yoghurt" type. Finished beverages represented homogeneous liquid, and their taste, smell, color and body were similar to the analogous products. However, it should be emphasized that soya beverages "Taste of Health" were marked by pleasant flavor and taste of Schisandra chinensis berries. The taste of soya was neutralized. The organoleptic analysis revealed that soya beverages "Taste of Health", stored at $6^{\circ} \mathrm{C}, 15^{\circ} \mathrm{C}$ and $25^{\circ} \mathrm{C}$, did not differ in properties. Dynamics of changes in the organoleptic characteristics of the samples of beverages, which were kept at a temperature of $6^{\circ} \mathrm{C}$ for 30 days is presented in table 6 . There was no significant difference among the varieties in their sweetness while there was significant difference in their color, texture and color $(\mathrm{p}<0.05)$. As shown on the table in the beverage "Taste of Health" with Chinese magnolia vine for 23 days of storage deteriorated smell other sensory characteristics have not changed. The changes in organoleptic indicators of beverage
"Taste of Health" with Chinese magnolia vine, fruit and berries with came later - at 27 days of storage. When storing beverages at higher temperatures $\left(15^{\circ} \mathrm{C}\right.$ and $\left.25^{\circ} \mathrm{C}\right)$ changes of organoleptic characteristics occurs earlier. Organoleptic assessment of the five-point scale after seven days of storage at different temperatures. "Taste of Health" with Chinese magnolia vine, fruit and berries are stored at a temperature of $6^{\circ} \mathrm{C}$ for seven days, had the highest score - 5 (Table 7)

In order to determine the shelf life of the beverages, we studied the changes in the titratable acidity and $\mathrm{pH}$ of the samples after addition of the starter during their storage. It should be noted that even on the 30th day these indicators did not change considerably. However, in three weeks a mild taste of soya was felt. Therefore, as a result of experiments conducted by us we have determined the shelf life of cultured soya beverages equal to 21 days at $\mathrm{t}=6^{\circ} \mathrm{C}$.

\section{Discussion}

At present the soya-based food products for the elderly people are given much preference, since soya contains up to $50 \%$ of digestible vegetable proteins (globulins, $\beta$ - and $\gamma$-conglycinins, glycinins), up to $24 \%$ of essential lipids, up to $25 \%$ of carbohydrates, up to $5 \%$ of dietary fibre, about $9 \%$ of micronutrients (macro- and microelements, phosphatides, vitamins E, B1, B2, B6, panthothenic acid, niacin, choline, folic acid, biotin) [37]. In terms of nutritional value soya proteins and fats are close to proteins of milk, fish and beef and contain all essential amino acids. Results of our studies also provide evidence of high nutritional and biological value of aqueous soya extract; this substance serves as an optimal basis for the geriatric dietary beverages.

In our work as a substrate for fermentation has been used combined composition: soy "milk" and aqueous-alcoholic extract of Schisandra chinensis. A number of research works deals with pharmacological evaluation of the effect of various preparations from Schisandra chinensis on central nervous system; there is also some evidence that Schisandra chinensis can be used in psychiatry, for treatment of

\begin{tabular}{|l|l|l|l|l|l|}
\hline Name of raw material & Raw materials consumption, kg \\
\hline Aqueous soya extract & “Taste of Health” with Chinese magnolia vine & $\begin{array}{l}\text { "Taste of Health" with Chinese magnolia vine, } \\
\text { fruit and berries }\end{array}$ & 880 \\
\hline Fruit and berry fillers & 955 & 75 \\
\hline Extract of Schisandra chinensis & - & 5 \\
\hline Starter: Lactobacillus bulgaricus and Streptococcus thermophilus (1:1) & 40 & 40 \\
\hline
\end{tabular}

Table 3: Formulas of beverages "Taste of Health" (kg per 1,000 kg).

\begin{tabular}{|l|l|l|}
\hline Characteristics & St. thermophilus & L. bulgaricus \\
\hline $\begin{array}{l}\text { Fermentation } \\
\text { of carbohydrates }\end{array}$ & Homo-fermentative, forms a predominantly lactic acid & $\begin{array}{l}\text { Homo-fermentative, } \\
\text { forms a predominantly lactic acid and a small amount of volatile acids }\end{array}$ \\
\hline $\begin{array}{l}\text { The optimum temperature of } \\
\text { development }\end{array}$ & $\begin{array}{l}\text { Thermophilic }-40-45^{\circ} \mathrm{C}, \\
\text { maximum }-50^{\circ} \mathrm{C}\end{array}$ & Thermophilic - $40-45^{\circ} \mathrm{C}$ \\
\hline Limit of acid & $110-115^{\circ} \mathrm{T}$ & $120_{-160^{\circ} \mathrm{T}}$ \\
\hline $\begin{array}{l}\text { Application } \\
\text { (for products) }\end{array}$ & Buttermilk, yogurt, fermented baked milk & Buttermilk, yogurt, fermented baked milk \\
\hline $\begin{array}{l}\text { The proteolytic activity of } \\
\text { fermentable }\end{array}$ & High & Lower than St. thermophilus \\
\hline Morphology & Lactic streptococci - cells are spherical form & $\begin{array}{l}\text { Lactic acid bacteria are rod-shaped, do not form spores, and do not } \\
\text { produce catalase }\end{array}$ \\
\hline Substrate & Milk sugar, mono- and disaccharides & Milk sugar, mono- and disaccharides \\
\hline Properties & $\begin{array}{l}\text { Characterized by their ability to form inviscid, viscous, } \\
\text { sometimes stringy clumps }\end{array}$ & Acid formers, enhance the flavor and aroma \\
\hline Clot & $\begin{array}{l}\text { Form of inviscid, viscous, sometimes stringy clumps, } \\
\text { founded strains forming clots acicular }\end{array}$ & $\begin{array}{l}\text { Form viscous clots, excessive development can lead to the formation of } \\
\text { viscous mucus consistency of the product }\end{array}$ \\
\hline
\end{tabular}

Table 4: Morphological and technological characterization of bacterial strains used in the technology of beverages. 
Citation: Palagina MV, Plekhova NG, Fishchenko ES, Cherevach El, Tekutyeva LA (2013) The New Combined Soy Beverage for Elderly People: the Technology Process and the Use. J Food Process Technol 4: 240. doi:10.4172/2157-7110.1000240

\begin{tabular}{|c|c|c|c|}
\hline \multirow[b]{2}{*}{ Name of parameter: } & \multirow{2}{*}{$\begin{array}{l}\text { Standard indicators of similar products: } \\
\text { Yoghurt GOST R } 51331-992.7 \% \\
\text { of fat }\end{array}$} & \multicolumn{2}{|c|}{ Indicators of developed products: } \\
\hline & & $\begin{array}{l}\text { "Taste of Health" } \\
\text { with Chinese } \\
\text { magnolia vine }\end{array}$ & $\begin{array}{l}\text { "Taste of Health" with } \\
\text { Chinese magnolia vine, fruit } \\
\text { and berries }\end{array}$ \\
\hline Weight fraction of protein, $\%$, no less than & 3.2 & 3.6 & 3.6 \\
\hline Weight fraction of fat, $\%$, no more than & 2.7 & 1.3 & 1.3 \\
\hline Weight fraction of total sugar, $\%$, & $\begin{array}{l}\text { as determined in technical } \\
\text { documentation }\end{array}$ & 2.1 & 2.2 \\
\hline Acidity, $\mathrm{T}^{\circ}$, no more than & $75-140$ & 47 & 49 \\
\hline Temperature when released from the factory, ${ }^{\circ} \mathrm{C}$, no higher than & $4 \pm 2$ & 6 & \\
\hline Phosphatase & none & none & \\
\hline \multicolumn{4}{|l|}{ Microbiological parameters: } \\
\hline Content of lactic-acid bacteria in CFU $/ \mathrm{cm}^{3}$, no less than & $1 * 10^{8}$ & $1 * 10^{8}$ & $1 * 10^{8}$ \\
\hline Escherichia coli group bacteria (coli-forms) in $0.1 \mathrm{~g}$ & not allowed & not found & \\
\hline Salmonella in $25 \mathrm{~g}$ & not allowed & not found & \\
\hline S. aureus in $1 \mathrm{~g}$ & not allowed & not found & \\
\hline Yeast, molds, CFU $/ \mathrm{cm}^{3}$, no more than & 10 & none & \\
\hline \multicolumn{4}{|l|}{ Toxic elements: } \\
\hline Lead, $\mathrm{mg} / \mathrm{kg}$, no more than & 0.1 & not found & \\
\hline Arsenic, mg/kg, no more than & 0.05 & 0.002 & \\
\hline Cadmium, $\mathrm{mg} / \mathrm{kg}$, no more than & 0.03 & not found & \\
\hline Mercury, mg/kg, no more than & 0.005 & not found & \\
\hline $\begin{array}{l}\text { Mycotoxins (aflatoxin M1), } \mathrm{mg} / \mathrm{kg} \text {, } \\
\text { no more than }\end{array}$ & 0.0005 & not found & \\
\hline $\begin{array}{l}\text { Antibiotics (chloromycetin, tetracycline group, streptomycin, penicillin), } \\
\mathrm{mg} / \mathrm{kg} \text {, no more than: }\end{array}$ & not allowed & not found & \\
\hline \multicolumn{4}{|l|}{ Pesticides, $\mathrm{mg} / \mathrm{kg}$, no more than: } \\
\hline Hexachlorocyclohexane ( $\alpha, \beta, \gamma$-isomers) & 0.05 & not found & \\
\hline DDT and its metabolites & 0,05 & not found & \\
\hline \multicolumn{4}{|l|}{ Radionuclides, $\mathrm{Bq} / \mathrm{kg}$, no more than: } \\
\hline Caesium-137 & 100 & not found & \\
\hline Strontium-90 & 25 & not found & \\
\hline
\end{tabular}

Table 5: Quality parameters of soya beverages "Taste of Health".

\begin{tabular}{|c|c|c|}
\hline $\begin{array}{l}\text { Name of } \\
\text { parameter }\end{array}$ & "Taste of Health" with Chinese magnolia vine & $\begin{array}{l}\text { "Taste of Health" with Chinese magnolia vine, fruit } \\
\text { and berries }\end{array}$ \\
\hline Consistence & \multicolumn{2}{|l|}{ Homogeneous liquid-type yogurt with small inclusions } \\
\hline \multicolumn{3}{|l|}{ Taste } \\
\hline \multicolumn{3}{|l|}{ Odor } \\
\hline \multicolumn{3}{|l|}{ Color } \\
\hline \multicolumn{3}{|c|}{ The shelf life of 7 days appearance } \\
\hline \multicolumn{3}{|l|}{ Taste } \\
\hline Odor & \multirow{2}{*}{\multicolumn{2}{|c|}{ Quality indicators have not changed }} \\
\hline Color & & \\
\hline \multicolumn{3}{|c|}{ The shelf life of 14 days appearance } \\
\hline \multicolumn{3}{|l|}{ Taste } \\
\hline Odor & \multirow{2}{*}{\multicolumn{2}{|c|}{ Quality indicators have not changed }} \\
\hline Color & & \\
\hline \multicolumn{3}{|c|}{ The shelf life of 20 days appearance } \\
\hline \multicolumn{3}{|l|}{ Taste } \\
\hline Odor & \multirow{2}{*}{ Quality indicators have not changed } & \\
\hline Color & & \\
\hline \multicolumn{3}{|c|}{ The shelf life of 23 days appearance } \\
\hline Taste & \multirow{3}{*}{$\begin{array}{l}\text { There was a pronounced smell of soy and a faint smell of fish, the other quality } \\
\text { indicators have not changed }\end{array}$} & \multirow{3}{*}{ Quality indicators have not changed } \\
\hline Odor & & \\
\hline Color & & \\
\hline \multicolumn{3}{|c|}{ The shelf life of 27 days appearance } \\
\hline Taste & \multirow{3}{*}{$\begin{array}{l}\text { There was a pronounced smell of soy and fish, stratification, precipitation was in the } \\
\text { form of pellets }\end{array}$} & \multirow{3}{*}{ There was a pronounced smell of soy, stratification } \\
\hline Odor & & \\
\hline Color & & \\
\hline \multicolumn{3}{|c|}{ The shelf life of 30 days appearance } \\
\hline $\begin{array}{l}\text { Taste } \\
\text { Odor } \\
\text { Color }\end{array}$ & $\begin{array}{l}\text { There was a sharp smell of soy, odors, fibration liquids, precipitation in the form of } \\
\text { pellets }\end{array}$ & There was a sharp smell of soy, odors, liquids bundle \\
\hline
\end{tabular}

Table 6: The organoleptic of beverage during storage. 


\begin{tabular}{|l|l|}
\hline Name of parameter: & Characteristics of parameters of yogurt (GOST R 51331 -99) \\
\hline Consistence & Homogeneous, moderately viscous. When using nutritional supplements flavor - with the presence of inclusions. \\
\hline color & Milky-white, uniform throughout the mass. When using nutritional supplements flavor - with the presence of color introduced ingredient. \\
\hline Taste and smell & Clean, sour milk. Using flavoring food additives - with the presence of introduced flavor ingredient. \\
\hline
\end{tabular}

Table 7: Organoleptic parameters of yogurt.

cardiovascular and some other diseases [17,19,38]. Schisandra chinensis intensifies positive reflexes, stimulates reflex excitability, enhances the eyes' light sensitivity, tones up the activity of the cardiovascular system, activates breathing, increases physical performance, improves memory, facilitates attention concentration, promotes composure, and accelerates adaptation to extreme factors. Schisandra chinensis was found to stimulate motor and secretory functions of the digestive tract and immunobiological reflexes, thus being very beneficial to the elderly people. Schisandra chinensis also produces positive effect on metabolism and blood composition; preparations from seeds of Schisandra chinensis increase the quantity of red blood cells and hemoglobin [38].

The traditional yogurt starter cultures (Lactobacillus delbrueckii subsp. Bulgaricus and Streptococcus thermophilus), proved to entering the digestive tract of humans, markedly stimulates the growth of bifidobacteria present in the intestines [39]. Experimentally and clinically proven that dairy products Streptococcus Thermophilus + Lactobacillus Delbrueckii subspecies. Bulgaric Bifidobacterium increase the amount of antibodies, cytokines, and the phagocytic activity of the cells. In substantiating the selection of suitable microorganisms, we have taken into account the fact that the leaven including two strains more resistant to adverse, non-standard factor of the environment than if it contains one strain. When selecting of leaven microflora also took into account its production and valuable performance and impact on the human.

By the production of starter cultures are valuable properties of the activity of acid, proteolytic and lipolytic activity, resistance to bacteriophage, organoleptic formed clot, etc. In our case, it was important to select a combination of strains indifferent to the effect of aqueous-alcoholic extract of Schisandra chinensis. In this case, the leaven should achieve of the desired acidity in the substrate in a short period of time, which should be nearly identical from batch to batch. For the efficient development of new products in the leaven should be integrated and balanced three parameters: speed of ripening, the texture and flavor of the finished product. Evaluations of starter cultures are usually done by instrumental measurements, sensory profiles, and charts.

Given all of the above for the preparation of the combined beverages were chosen two types of microorganisms: Lactobacillus delbrueckii subsp. bulgaric и Streptococcus thermophilus. Lactobacilli in the normal metabolism of producing lactic acid, hydrogen peroxide produce lysozyme, other substances with antibiotic activity: laktotsin, plantaritsin, nisin, and other substances [40]. Lactobacilli assigned immunomodulatory role, including stimulation of the phagocytic activity of neutrophils, macrophages, immunoglobulin synthesis, the formation of interferon. The role of lactic acid bacteria in the recycling of bile acids and cholesterol in maintaining the balance of the composition of microbial populations after taking antibiotics [40]. In turn in Streptococcus genus, S. thermophilus is the only one food species among commensal and opportunistic pathogen species [41]. S. thermophilus has maintained a well-developed nitrogen metabolism whereas its sugar catabolism has been subjected to a high level of degeneracy due to a paucity of carbon sources in milk [42]. Using the selected types of bacteria for making fermented beverages, we have provided the probiotic effect of finished products, which is mainly caused by lactic acid bacteria with antibiotic activity against pathogenic and opportunistic microorganisms and their ability to take root in the human gut. Given that the fermented soy beverages are low titratable acidity $(400 \mathrm{~T})$, and thus, fresh flavor, to improve organoleptic characteristics invited acidified soy "milk" by the solution of succinic acid. The positive impact of this component is caused by the fact that succinic acid is an immunomodulator.

Thus, the combined substrate fermented probiotic microorganism has a positive effect on the quality of the final product. Accumulation of a large amount of probiotic microorganisms and their metabolic products in the drinks can adjust the composition of the human intestinal flora. These components have positive effects on secretion and digestive enzyme activity and improve the absorption of vitamins and minerals (calcium, magnesium, and phosphorus). This combined beverage in the diet of older people will be a significant addition to the correction of osteoporosis and the prevention of other diseases. In turn, the effect of Schisandra chinensis on an organism can be attributable to its unique chemical composition. Its berries contain a great number of organic and contain up to $50.4 \%$ of oils, including $5.7 \%$ of essential oils, as well as chlorophyll, sterols, vitamin $\mathrm{E}$ (up to $3 \mathrm{mg} \%$ ), and microelements (copper, manganese, nickel, zinc). The oil of Schisandra chinensis seeds consists mainly of glycerides of unsaturated fatty acids linolenic acid and oleic acid. Tonic agents are represented by a complex of individual substances - methyl ethers of phenolic lignan compounds. The polar fraction of lignans containing the complex of five lignan compounds, such as schizandrines, schizandrol and homizine A, has high biological value. These components affect on the normalization of biochemical and physiological functions of the human organism. Based on the research data, it may be concluded that the developed cultured soya beverages are adequate dietary products and can be used by the elderly people as functional geriatric products.

\section{References}

1. Samsonov MA (2001) Concept of balanced nutrition and it's significance in studying the mechanisms of the therapeutic effects of food. Vopr Pitan 70: 3-9.

2. Donskaya GA, Skobeleva NV, Korolev AA (2000) Dairy products for prevention of osteoporosis. Dairy industry 9: 10-11.

3. Zaporozhsky AA, Mikhailova MG (2005) Possibilities for development of combined meat products for geriatric dietary purpose. Proceed of higher Educ Institut Food processing 1: 44-46.

4. Sanders ME (2008) Probiotics: definition, sources, selection, and uses. Clin Infect Dis 46 Suppl 2: S58-61.

5. Jooyandeh H (2011) Soy Products as Healthy and Functional Foods. MiddleEast J of Scientific Research 7: 71-80.

6. Liu K (2004) Soybeans as functional foods and ingredients. AOCS Publishing USA.

7. Deshpande S, Bargale P, Jha K (2008) Suitability of soymilk for development of shrikhand. J Food Science and Technol 45: 284-286.

8. Kale RV, Pandhare GR, Satwase AN, Goswami D (2012) Effect of Different Concentration of Orange Juice on Quality Characteristics of Soya Milk Blended Beverage. J Food Process Technol 3: 140

9. Wang B, Xiong Y, Wang C (2001) Physicochemical and Sensory Characteristics of Flavored Soymilk during Refrigeration Storage. J Food Quality 24: 513-526. 
Citation: Palagina MV, Plekhova NG, Fishchenko ES, Cherevach El, Tekutyeva LA (2013) The New Combined Soy Beverage for Elderly People: the Technology Process and the Use. J Food Process Technol 4: 240. doi:10.4172/2157-7110.1000240

10. Shu XO, Jin F, Dai Q, Wen W, Potter JD, et al. (2001) Soyfood intake during adolescence and subsequent risk of breast cancer among Chinese women. Cancer Epidemiol Biomarkers Prev 10: 483-488.

11. Beaglehole R (1990) International trends in coronary heart disease mortality, morbidity, and risk factors. Epidemiol Rev 12: 1-15.

12. Nagata C, Takatsuka N, Kurisu Y, Shimizu H (1998) Decreased serum tota cholesterol concentration is associated with high intake of soy products in Japanese men and women. J Nutr 128: 209-213.

13. Levi F, Lucchini F, Negri E, Vecchia CL (2002) Trends in mortality from cardiovascular and cerebrovascular diseases in Europe and other areas of the world. Heart 88: 119-124

14. Isagulyan EA, Sagun GV, Efimov AN (2001) Formulation of juice-containing beverages on the basis of soya milk. Proceedings of higher educat Institut Food processing 4: 55-56.

15. Chiu HF, Chen TY, Tzeng YT, Wang CK (2013) Improvement of liver function in humans using a mixture of schisandra fruit extract and sesamin. Phytother Res 27: 368-373.

16. Chien CF, Wu YT, Tsai TH (2011) Biological analysis of herbal medicines used for the treatment of liver diseases. Biomed Chromatogr 25: 21-38.

17. Chiu PY, Mak DH, Poon MK, Ko KM (2002) In vivo antioxidant action of a lignan-enriched extract of Schisandra fruit and an anthraquinone-containing extract of Polygonum root in comparison with schisandrin B and emodin. Planta Med 68: 951-956.

18. Chen N, Chiu PY, Ko KM (2008) Schisandrin B enhances cerebral mitochondrial antioxidant status and structural integrity, and protects against cerebra ischemia/reperfusion injury in rats. Biol Pharm Bull 31: 1387-1391.

19. Lam PY, Ko KM (2012) Schisandrin B as a hormetic agent for preventing agerelated neurodegenerative diseases. Oxid Med Cell Longev 2012: 250825

20. Lin RD, Mao YW, Leu SJ, Huang CY, Lee MH (2011) The immuno-regulatory effects of Schisandra chinensis and its constituents on human monocytic leukemia cells. Molecules 16: 4836-4849.

21. Szeto YT, Wong SC, Wong JW, Kalle W, Pak SC (2011) In vitro antioxidation activity and genoprotective effect of selected Chinese medicinal herbs. Am J Chin Med 39: 827-838.

22. Pavlishko GN, Riabinina OV, Zhiliakova TA, Sakharov llu, Gerzhikova VG, et al. (2005) [Oxidase-peroxidase method for determination of ethanol in fermented musts and wine products]. Prikl Biokhim Mikrobiol 41: 686-692.

23. Magné C, Larher F (1992) High sugar content of extracts interferes with colorimetric determination of amino acids and free proline. Anal Biochem 200: 115-118.

24. Chang Y, Su G, Yin C, Zhang J, Bu H (2005) [Study on dynamics of tannin in different growth phase of Cynomorium songaricum]. Zhong Yao Cai 28: 643645.

25. Huyke C, Engel K, Simon-Haarhaus B, Quirin KW, Schempp CM (2007) Composition and biological activity of different extracts from Schisandra sphenanthera and Schisandra chinensis. Planta Med 73: 1116-1126.

26. Milder IE, Arts IC, van de Putte B, Venema DP, Hollman PC (2005) Lignan contents of Dutch plant foods: a database including lariciresinol, pinoresinol, secoisolariciresinol and matairesinol. Br J Nutr 93: 393-402.

27. Baiano A, Terracone C, Gambacorta G, La Notte E (2009) Phenolic conten and antioxidant activity of Primitivo wine: comparison among winemaking technologies. J Food Sci 74: C258-267.

28. Tian S, Nakamura K, Cui T, Kayahara H (2005) High-performance liquid chromatographic determination of phenolic compounds in rice. J Chromatog A 1063: 121-128.

29. AOAC (2005) Official methods of analysis. Association of official analytical chemists. 15th ed. Washington, DC, USA.

30. Aflatoxin MI 30/15 (2007) Enzyme immunoassay for the quantitative analysis of aflatoxin M1 in milk, milk powder and cheese, RIDASCREEN ${ }^{\circledR}$ Aflatoxin M 30/15. Instruction booklet. R-Biopharm AG, Darmstadt, Germany. p. 1-18.

31. Stijve T (1987) Organochlorines and organophosphorus pesticides. In: Thei $\mathrm{HP}$, Zeumer $\mathrm{H}$, editors. Manual of pesticide residue analysis. Vol. 1. Germany: Wiley-VCH Verlag GmbH. p. 297-308

32. CAMPBELL JE, MURTHY GK, GOLDIN AS, ROBINSON HB, STRAUB CP, e al. (1959) The occurrence of strontium-90, iodine-131, and other radionuclides in milk; May, 1957, through April, 1958. Am J Public Health Nations Health 49 225-235.

33. World Health Organization (2007) WHO monographs on selected medicina plants 3: 296-313.

34. Hancke JL, Burgos RA, Ahumada F (1999) Schisandra chinensis (Turcz.) Baill. Fitoterapia 70: 451-471.

35. Szopa A, Ekiert H (2012) In vitro cultures of Schisandra chinensis (Turcz.) Baill. (Chinese magnolia vine)-a potential biotechnological rich source of therapeutically important phenolic acids. Appl Biochem Biotechnol 166: 1941 1948

36. Lee EJ, Yoo KS, Patil BS (2010) Development of a rapid HPLC-UV method for simultaneous quantification of protodioscin and rutin in white and green asparagus spears. J Food Sci 75: C703-709.

37. Aoyama T, Fukui K, Nakamori T, Hashimoto Y, Yamamoto T, et al. (2000) Effect of soy and milk whey protein isolates and their hydrolysates on weight reduction in genetically obese mice. Biosci Biotechnol Biochem 64: 2594-2600.

38. Zorikov PS (2004) Main medicinal plants of Primorsky region. Vladivostok: Dalnauka $184 \mathrm{p}$

39. Schwab C, Gänzle M (2011) Lactic acid bacteria fermentation of human milk oligosaccharide components, human milk oligosaccharides and galactooligosaccharides. FEMS Microbiol Lett 315: 141-148.

40. Ashraf R, Shah NP (2011) Selective and differential enumerations of Lactobacillus delbrueckii subsp. bulgaricus, Streptococcus thermophilus, Lactobacillus acidophilus, Lactobacillus casei and Bifidobacterium spp. in yoghurt--a review. Int J Food Microbiol 149: 194-208.

41. Delorme C (2008) Safety assessment of dairy microorganisms: Streptococcus thermophilus. Int J Food Microbiol 126: 274-277.

42. Hols P, Hancy F, Fontaine L, Grossiord B, Prozzi D, et al. (2005) New insights in the molecular biology and physiology of Streptococcus thermophilus revealed by comparative genomics. FEMS Microbiol Rev 29: 435-463. 